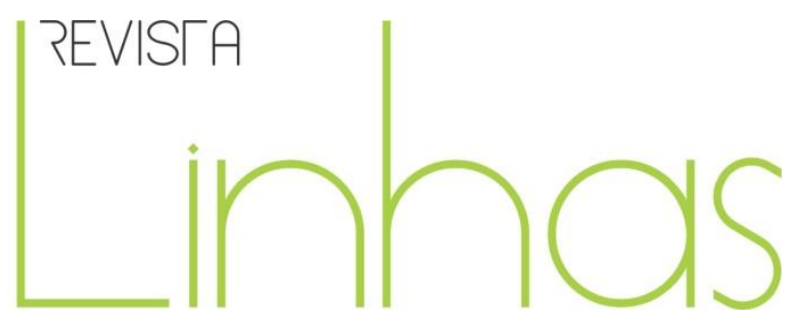

\title{
Aparelhos privados de hegemonia e discursos privatistas no Ensino Médio amapaense
}

\begin{abstract}
Resumo
A privatização da educação pública no Brasil se manifesta de diversas formas, incluindo a participação de grupos empresariais e de Aparelhos Privados de Hegemonia (APH) na definição da agenda educacional. O objetivo desse texto foi o de analisar o discurso de um desses Aparelhos, o Instituto de Corresponsabilidade pela Educação (ICE), na implementação do Ensino Médio público em Tempo Integral (EMTI) no Amapá no período entre 2016 e 2018. Tivemos em vista identificar os seus mecanismos de atuação na implementação dessa política e investigar o discurso privatista no que tange à gestão das Escolas Estaduais em Tempo Integral no estado. A pergunta central que orientou a investigação foi: que discursos e práticas têm se constituído na relação entre os interesses privatistas e os sujeitos envolvidos na implementação do EMTI no Amapá, após 2016? Para alcançar os objetivos propostos, realizamos exame de documentos nacionais e estaduais referentes à Política de Educação em Tempo Integral e entrevistas semiestruturadas com 12 sujeitos. Foi possível concluir que há no EMTI uma política gerencialista que expressa a cultura de metas, planilha de indicadores, índices de produtividade, avaliação e a ideologia da qualidade educacional; ademais, que a atuação governamental, em aliança com um Aparelho Privado de Hegemonia burguesa, é fundamental para implementação da ETI no Amapá e tem reforçado a mercantilização do processo escolar, garantindo a hegemonia das políticas neoliberais no âmbito da educação.
\end{abstract}

Palavras-chave: Aparelho Privado de Hegemonia; educação em tempo integral; ensino médio; relações público-privadas na educação; rede estadual de ensino.

\author{
José Almir Viana Nunes \\ Universidade Federal do Amapá - \\ UNIFAP - Macapá/AP - Brasil \\ vianunes@hotmail.com
}

\footnotetext{
Para citar este artigo:

NUNES, José Almir Viana. Aparelhos privados de hegemonia e discursos privatistas no Ensino Médio amapaense. Revista Linhas. Florianópolis, v. 22, n. 49, p. 156-186, maio/ago. 2021.
} 


\title{
Private hegemony and privatist speeches in amapaense high school
}

\begin{abstract}
The privatization of public education in Brazil manifests itself in several ways, including the participation of business groups and Private Hegemony Devices (APH) in defining the educational agenda. The purpose of this text was to analyze the speech of one of these Devices, the Institute of Coresponsibility for Education (ICE), in the implementation of public high school full time (EMTI) in Amapá in the period between 2016 and 2018. We aimed to identify its mechanisms of action in the implementation of this policy and to investigate the privatist discourse with regard to the management of State Schools Full-Time in the state. The central question that guided the investigation was: what discourses and practices have been constituted in the relationship between privatist interests and the subjects involved in the implementation of EMTI in Amapá, after 2016? To achieve the proposed objectives, we carried out an examination of national and state documents referring to the Full-Time Education Policy and semi-structured interviews with twelve subjects. For the analysis of the interviews, Mikhail Bakhtin's (1997) discourse theory was considered, which allowed us to conclude that there is a managerialist policy in EMTI that expresses the culture of goals, indicator spreadsheet, productivity indexes, evaluation and the ideology of quality educational. It also made it possible to conclude that government action, in alliance with a Private apparatus of bourgeois Hegemony, is fundamental for the implementation of ETI in Amapá and has reinforced the commercialization of the school process, guaranteeing the hegemony of neoliberal policies in the field of education.
\end{abstract}

Keywords: Private Hegemony Appliance; full-time education; high school; public-private relations in education; state education network. 
A privatização da Educação Básica no Brasil tem sido campo vasto de pesquisa por suscitar grande preocupação quanto à modificação da disposição da educação, como direito e bem público a ser provido pelo Estado. Tal preocupação decorre do fato de que a educação pública vem sendo negociada e subordinada à lógica do lucro, movimento identificável desde a década de 90, século do XX, que culminou na configuração de um processo de punção do fundo público em benefício do setor privado. No nível nacional, os projetos de política educativa têm sido fortemente influídos pela efetivação das Parcerias Público-Privadas na educação. Nesse prisma, Evangelista (2021) indica que Aparelhos Privados de Hegemonia (APH) são frações da burguesia que disputam a conformação do pensamento e do corpo humanos e não se cansam de renovar seus discursos e suas estratégias políticas para que seu opositor necessário, o trabalhador, seja derrubado.

Tanto é que, mais recentemente, o Banco Mundial (BM), ao apresentar sua estratégia de parceria para o Brasil, informou que para o período de seis anos (anos fiscais de 2018 a 2023), buscar-se-á "alavancar a iniciativa e o investimento do setor privado, identificando oportunidades para ganhos de eficiência, enfatizando a importância de um sólido quadro regulatório e uma governança forte para avaliar e compartilhar riscos adequadamente." (BANCO MUNDIAL, 2017). Tal instituição canaliza suas ações ciente de que a adaptação da força de trabalho mundial às demandas do mercado futuro necessita de saúde, educação e acesso à proteção social, ainda que mínimos, e que ofertar tais benefícios exigiria novas fontes de receita. Por isso, o Banco desenvolveu uma "Abordagem Sistêmica para Melhores Resultados em Educação" (SABER), contemplando várias formas de engajamento do setor privado na Educação e revela as causas de seu interesse pela educação ao noticiar, em seu site, o quanto é custoso formar o trabalhador do futuro:

A formação de capital humano ${ }^{1}$ começa quando a pessoa ainda está na barriga da mãe; daí a importância de assegurar nutrição de qualidade desde cedo. Continua quando se dá à criança acesso a creches, cuidados preventivos e curativos, saneamento básico e outros benefícios. Cada

\footnotetext{
${ }^{1}$ A TCH foi desenvolvida por Theodore Schultz nas obras O valor econômico da educação (1967) e O capital humano: investimentos em educação e pesquisa (1973).
} 
dólar investido em programas de qualidade na primeira infância gera um retorno de US\$ 6 a US\$ 17. (BANCO MUNDIAL, 2018)

Como se vê, para o BM, educação é projeto de longo prazo. Executá-lo requer conhecimento, planejamento, estratégia e intelectuais orgânicos do capital afeitos a lançar as teias da financeirização sobre as políticas sociais, os recursos e os fundos públicos. Gramsci (1978, p. 37) já afirmava que "toda relação de hegemonia é necessariamente uma relação pedagógica", indicando assim a potencialidade educativa dos APHs burgueses sobre a classe trabalhadora. Nessa relação, a sociedade civil é o eixo indispensável de exercício do governo por meio da ação política e da disputa hegemônica que cria e propaga ideais, os quais se efetivam como senso comum e ratificam o modo de vida capitalista. Por isso, “[...] o Estado tem e pede o consenso, mas também 'educa' este consenso através das associações políticas e sindicais, que, porém, são organismos privados" (GRAMSCI, 2011, p. 119). Assim, as reformas que estão desfigurando a escola pública em todos os níveis só podem ser compreendidas no bojo dessa totalidade.

O que vem sendo constatado em diferentes contextos e especificidades no cenário político-educacional brasileiro é a relação entre instituições privadas e a gestão da educação pública. Nesse sentido, o presente trabalho apresenta os "Aparelhos Privados de Hegemonia e discursos privatistas no Ensino Médio Amapaense.” O fomento à implementação de Educação em Tempo Integral para o Ensino Médio no Amapá iniciou formalmente em setembro de 2016, ocasião em que a Secretaria de Estado da Educação (SEED) se reuniu com o Ministério da Educação (MEC) para a devida discussão. Foi pelo Decreto 4.446/2016 (AMAPÁ, 2016b) e pela Lei 2.283/2017 (AMAPÁ, 2017c) que se instituiu o Programa de Escolas do Novo Saber, bem como pela Portaria MEC 1.023, de 4 de outubro de 2018 (BRASIL, 2018), que legitima tal adesão.

No decorrer do processo de implementação, dentre as ações investidas, observase a atuação de grupos privatistas na SEED e nas oito escolas selecionadas inicialmente para o EMTI. Como exemplo, destaca-se o ICE e seus parceiros, o Instituto Sonho Grande (ISG) e o Instituto Natura. A pesquisa teve como foco o ICE, pois é o grupo empresarial com maior presença e influência no Programa das Escolas do Novo Saber. (AMAPÁ. GEA, 2016a). Os trabalhos realizados por eles são de consultoria, formação de gestores e professores, bem como avaliação e monitoramento das escolas. 
O enfoque epistemológico adotado é o método materialista-histórico que, conforme Gamboa (2007), permite conhecer a realidade concreta no seu dinamismo e nas suas inter-relações. Dessa forma, os loci desta pesquisa abrangem especialmente as oito primeiras Escolas Estaduais (EE) que fazem parte do Programa de Educação em Tempo Integral do Governo Federal, consideradas aqui “escolas-piloto" que, no ano letivo de 2017, ofertaram apenas $01^{\circ}$ ano do Ensino Médio na modalidade integral e os demais anos $\left(2^{\circ}\right.$ e $\left.3^{\circ}\right)$ foram implantados progressivamente até 2019. A intenção foi a de relacionar as questões levantadas pela pesquisa com a realidade concreta, considerando os discursos dos sujeitos pesquisados (um consultor do Ministério da Educação/MEC, dois consultores do ICE, um Gerente geral da Equipe de implementação do EMTI da SEED e oito gestores das oito escolas-loci) na sua relação com o contexto de implementação do EMTI no Amapá.

\section{A operacionalização do programa Escolas do Novo Saber no Amapá}

O Programa de Educação em Tempo Integral na rede estadual de ensino do Amapá iniciou formalmente em setembro de 2016, mas foi pelo Decreto n. 4.446, de 19 de dezembro de 2016 (AMAPÁ, 2016b), e em conformidade à Portaria n. 1.145, de 10 de outubro de 2016 (BRASIL, 2016), que o Governo do Estado do Amapá (GEA) criou o Programa, no âmbito de oito escolas selecionadas pelo MEC: Colégio Amapaense, José Firmo do Nascimento, Maria do Carmo Viana dos Anjos, Raimunda Virgolino, Tiradentes, Alberto Santos Dumont, Augusto Antunes e Elizabeth Picanço Esteves. Vale destacar que cada estado, após aderir ao Programa Federal, deveria criar um nome para tal e, neste caso, o Amapá designou como Escolas do Novo Saber. É importante destacar que a política de EMTI continua se expandindo na rede de ensino amapaense. Atualmente o Programa Escolas do Novo Saber constitui um universo de 23 escolas.

Dito isso, cabe analisar o slogan "Escolas do Novo Saber - Mais educação, melhores cidadãos", demonstrado adiante na figura 1, que representa as escolas de EMTI no Amapá. Na área da Política Educacional, Evangelista, Shiroma e Santos (2014) discutem como os slogans são utilizados como eixo dos discursos conservadores e forjam um senso 
comum sobre a necessidade de reformas do Estado e educacionais para a superação de crises.

Figura 1- Slogan da ETI amapaense: Escolas do Novo Saber (2017)

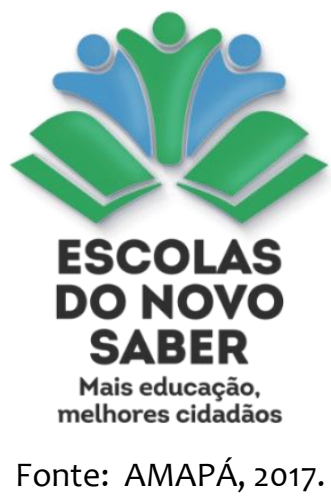

O slogan em análise tem forte similaridade com a legislação nacional concernente à reforma educacional denominada como "Novo Ensino Médio". Nota-se que a palavra "Novo" consta em ambos os slogans e esconde a essência das intenções presentes no ideário de educação, escola e formação humana. "Assim, podemos constatar, por exemplo, como característica marcante nos documentos de políticas públicas dos organismos internacionais a presença do discurso fundador que ressignifica o que veio antes e institui aí uma memória outra." (ORLANDI, 1993, p. 13). As palavras "novo," assim como "mais" e "melhor," dizem respeito a que conjunto de valores? Melhor, dentro de que concepção de educação? São as palavras com aura positiva ${ }^{2}$ e fazem parte das reformas educacionais iniciadas nos anos 1990 no Brasil e buscam imprimir valores hegemônicos burgueses.

Gramsci (1989) destacou que o uso corrente de certos conceitos pode aparentar peculiaridade no fazer diário, resultando assim na conformação, pois a linguagem, neste sentido produz, hegemonia. Trata-se de um lado, da racionalização neoliberal que justifica o atraso nacional pela ausência de uma "qualidade" na educação e defende a inovação da produção e desenvolvimento tecnólogico; para tal, o empresariado seria o ideal parceiro.

\footnotetext{
${ }^{2}$ Contreras (2002 apud SHIROMA; SANTOS, 2014, p. 27) analisa o uso indiscriminado de slogans no campo educacional. Refere-se aos termos adotados de certa "aura positiva" usados em excesso de modo que acabam se desgastando e sendo esvaziados de todo conteúdo crítico que o constituíam. Dentre essas expressões cita a qualidade da educação.
} 
De outro lado, a classe trabalhadora busca a educação como direito humano e bem público com potencial emancipatório. Mas afinal, o que estaria em disputa? Evangelista e Triches (2014, p. 49) indicam: “Podemos afirmar que está em disputa a capacidade de pensar, de refletir, de discernir do professor - e, por consequência, a de seus alunos, filhos de trabalhadores e trabalhadores que frequentam a escola pública."

Para compor a gestão das escolas, em atendimento à exigência do Decreto GEA 4.446/2016 (AMAPÁ, 2017C), foram realizados seis Processos Seletivos Simplificados (PSS) internos exclusivos para servidores efetivos do quadro de profissionais do Estado que quisessem atuar nas Escolas do Novo saber. Em conformidade à Lei n. 2.283/2017, entendese por Escolas de Ensino Médio em Tempo Integral:

as unidades de Ensino Médio com funcionamento em tempo integral, orientadas por conteúdos pedagógicos, métodos didáticos, gestão curricular e administrativa próprios, vinculadas à Secretaria Estadual de Educação, com regulamentação prevista em normas específicas, as quais têm por finalidade ampliar o tempo de permanência dos estudantes na Instituição de Ensino, garantindo-lhe formação integral. (AMAPÁ, 2017C)

É possível constatar que o referido conceito está claramente atrelado à ampliação do tempo escolar e ainda à formação integral. Todavia, não se esclarece quais são os fundamentos epistemológicos que sustentam tal concepção. O plano de atividades ofertadas constitui aulas dos componentes curriculares da base nacional comum (Língua Portuguesa, Língua Estrangeira, Matemática, Biologia, Química, Física, Educação Física, Sociologia, Filosofia, Artes, História, Geografia) e da parte diversificada (Disciplinas eletivas, Projeto de Vida, Estudo orientado, Avaliação, Pós-Médio, Práticas Experimentais). Os alunos iniciam o horário escolar às 7 h3omin e saem às $17 \mathrm{~h}$, com intervalo de 2omin, seja pela manhã ou no turno da tarde, sendo o almoço com duração de 1 h2omin.

Para implementação dessa política, faz-se indispensável um planejamento e investimentos para a estrutura física. Consta-se que as escolas ainda se encontram em reformas para atender o modelo de tempo integral e o ICE garantiu a formação aos profissionais e à realização das atividades necessárias para o trabalho pedagógico. Assim, desenha-se um cenário em que é possível identificar a privatização da educação que, 
segundo Adrião (2017), se estabelece em três dimensões: privatização da gestão da educação, privatização do currículo e privatização da oferta educacional, as quais, respectivamente, caracterizam-se pelos seguintes aspectos:

[...] pela transferência da gestão educacional pública para o setor privado, corporativo ou não; pela transferência da elaboração e gestão dos currículos escolares para corporações privadas ou para setores autoproclamados 'não lucrativos' e ainda pelo aprofundamento da privatização da oferta educacional por meio da ampliação de políticas de choice. (ADRIÃO, 2017, p. 1)

Conforme a incidência e organização aparentemente filantrópica e autônoma do empresariado no campo das políticas educacionais, é que se observa substantivamente a implementação das políticas educacionais recentes. A exemplo disso, destaca-se o Instituto de Corresponsabilidade pela Educação, cujo trabalho é de consultoria; formação de gestores e professores; avaliação e monitoramento das escolas. Isso posto, apresentase uma incursão sobre a trajetória somente do ICE, o qual é o foco da pesquisa, pois é o grupo empresarial com maior influência no Programa das Escolas do Novo saber, embora tenha nas suas atividades a parceria do Instituto Sonho Grande (ISG) 3 e a do Instituto Natura4.

\section{ICE: Aparelho Privado de Hegemonia no EMTI amapaense}

Os APHs vêm sendo pesquisados em alguns trabalhos, dentre os quais citamos Lamosa (2020), que os denomina de "Tubarões da Educação", fazendo referência às classes dominantes que operam na Educação controlando as instituições de ensino e os trabalhadores da educação, além de determinarem políticas educacionais em várias dimensões: avaliação, currículo e gestão das escolas. Disso, resulta a privatização da educação pública e dos instrumentos de subsunção do trabalho escolar aos interesses

\footnotetext{
3 Fundado em 2015, identifica-se como uma Organização não Governamental com sede em São Paulo, atuando na área educacional, em especial no Ensino Médio Integral. Para outras informações, acesse o site http://www.institutosonhogrande.org.

${ }^{4}$ Fundado em 2010, identifica-se como uma Organização da Sociedade Civil de Interesse Público (OSCIP), com atuação independente das operações da empresa e que passa a investir e monitorar os recursos arrecadados pela comercialização da linha Natura Crer para Ver. Tem sede em São Paulo e atua com ênfase na área educacional. Para outras informações, acesse https://www.institutonatura.org.br.
} 
dominantes, bem como a expansão mundial da hegemonia do capital promovida pelos organismos internacionais, ou do "partido do estrangeiro que representa sua subordinação e servidão econômica às nações ou a um grupo de nações hegemônicas" (GRAMSCI, 2011, p. 20).

O ICE identifica-se como uma entidade sem fins econômicos, criada em 2003 por um grupo de empresários motivados a conceber um novo modelo de Escola. Partindo desse objetivo, foi então que se buscou resgatar o padrão de excelência da primeira escola não-eclesiástica do Nordeste, antigamente chamada de Liceu, a qual foi referência e teve estudantes ilustres, como Epitácio Pessoa, Ariano Suassuna, Clarice Lispector; exgovernadores, como Agamenon Magalhães e Joaquim Francisco. Foi assim que o então decadente e secular Ginásio Pernambucano5, localizado em Recife, recebeu uma grande reforma. Quanto à visão, busca "ser reconhecido como uma organização de referência na concepção, produção e irradiação de conhecimentos, tecnologias e práticas educacionais, com vista à qualificação do ensino básico público e gratuito, transformando estas práticas em políticas públicas.” Quanto à sua missão, declara: “contribuir objetivamente para a melhoria da qualidade da Educação Básica Pública, através da aplicação de inovações em conteúdo, método e gestão, objetivando à formação integral do jovem nas dimensões pessoal, social e produtiva." (ICE, 2019). Há na visão e missão do ICE muitas "palavras com aura positiva" para se criar o consenso, mas na essência estão os pressupostos neoliberais, como a reafirmação da crise da qualidade da educação e a formação de um indivíduo (dimensão produtiva) para o capital.

Por isso, indica como fundamentos a causa do "ensino público de qualidade," a marca da "corresponsabilidade" e o desafio da criação de novos desenhos institucionais. Registra-se também que a recuperação do antigo prédio do Ginásio Pernambucano partiu de uma "visão de escola pública de qualidade", para desenvolver uma nova estratégia de enfrentar os desafios do Ensino Médio, no entanto revigorada com uma nova forma de

\footnotetext{
${ }^{5}$ Foi a segunda escola pública mais antiga em operação no Brasil, sendo oficialmente inaugurado em 1853 pelo imperador D. Pedro I. Abandonado, o prédio estava caindo até que um ex-aluno tomou conhecimento dessa situação por acaso, passando em frente ao local. Em 2002, mobilizou um grupo de colegas empresários e, juntos, iniciaram o trabalho de recuperação. A reforma do Ginásio Pernambucano não se limitava apenas ao prédio, pois se fazia necessária a revitalização da valiosa biblioteca e do museu, bem como a preocupação com a qualidade do ensino público que sempre caracterizara o educandário. $O$ projeto de recuperação do prédio levou dois anos e meio e teve um investimento de quase 3 milhões de reais. (ICE, 2019).
} 
atuação do setor privado, incluindo os aspectos pedagógicos e de gestão, além de uma coparticipação financeira junto ao Governo Pernambucano.

Em 2004, o Ginásio Pernambucano abria suas portas à primeira turma, que passaria a vivenciar uma "educação integral em tempo integral." Nos anos seguintes, iniciou-se o processo de expansão do Modelo, com a presença do ICE, investidores e parceiros técnicos junto às Secretarias de Educação - municipais e estaduais - apoiando a implantação nos segmentos do Ensino Médio e nos anos finais do Ensino Fundamental. Até o ano de 2020, estava em curso a implantação de um piloto do Modelo nos anos iniciais do Ensino Fundamental, passando assim o ICE a atender a todas as etapas da Educação Básica. Quatro anos após, o ICE iniciou o processo de expansão do Modelo para outros municípios e Unidades da Federação (UF). Nesse período, atuou em mais de 800 Escolas da Escolha ${ }^{6}$, em oito Unidades Federativas (UF) e continua com um intenso trabalho de mobilização em prol da realização de sua Visão.

No período de 2004 a 2018, sua atuação abarcou cerca de 747.600 estudantes, 40.050 educadores e 1.335 escolas públicas brasileiras, sendo destas seis dos anos iniciais e 248 dos anos finais do Ensino Fundamental, 917 do Ensino Médio e 164 do Ensino Médio Integrado à Educação Profissional. Observe a amplitude de atuação do ICE (2021):

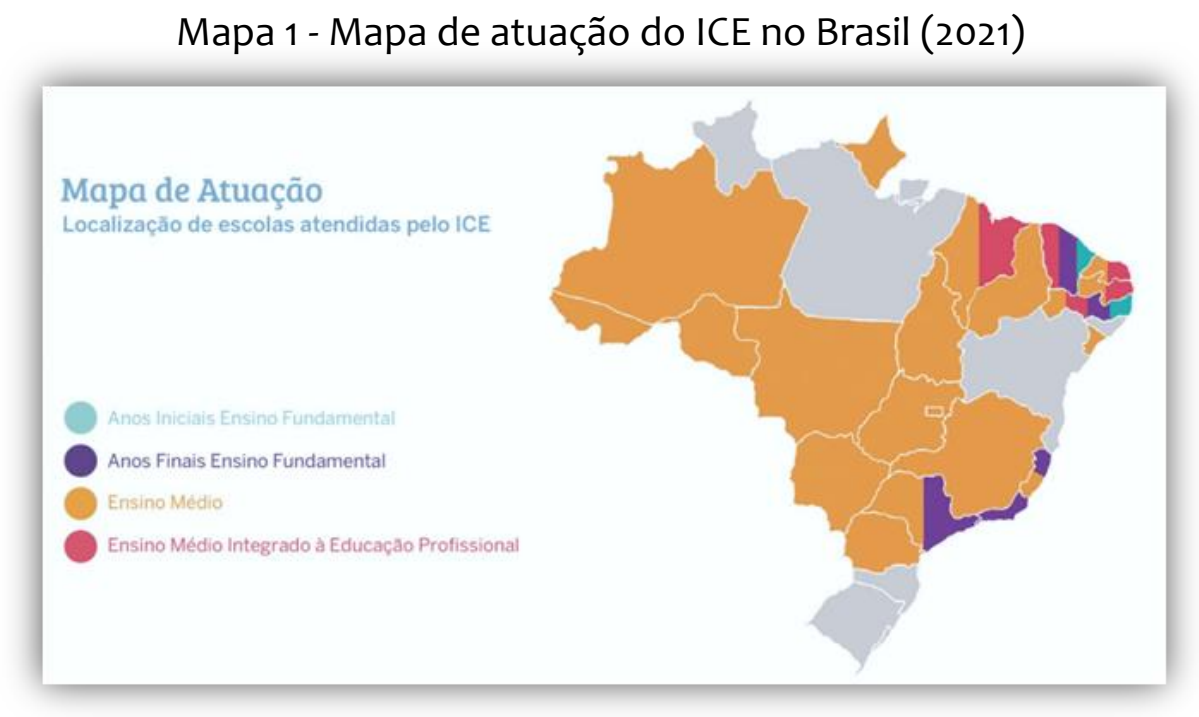

Fonte: ICE (2021).

\footnotetext{
${ }^{6}$ O Modelo da Escola da Escolha é operacionalizado por meio de uma estratégia fundamental: a ampliação do tempo de permanência de toda a comunidade escolar, equipes de gestão, professores, corpo técnicoadministrativo e os estudantes, de forma a viabilizar o projeto escolar de educação integral (ICE, 2019).
} 
Percebe-se (Mapa 1) que O ICE atua de forma bastante abrangente no Brasil, pois de acordo com o mapa, dos 26 estados e do Distrito Federal, ele não exerce atividades em apenas seis, assim distribuídos: Norte (Roraima e Pará); Nordeste (Alagoas e Bahia); Sul (Santa Catarina e Rio Grande do Sul).

Afirma o ICE que a base para a formulação do Modelo foi o compromisso pleno com a integralidade da ação educativa. Essa integralidade foi concretizada por meio dos seguintes dispositivos: Artigo $2^{\circ}$ da LDB 9.394/967 e Artigo $3^{\circ}$ da Constituição Federal do Brasil $^{8}$ (visão de homem e sociedade); finalidades da Educação - UNESCO'; alinhamento político e conceitual dos documentos: - Paradigma do Desenvolvimento Humano (PNUD) - Códigos da Modernidade elaborados pelo filósofo e educador colombiano Bernardo Toro. Atualmente, o organograma do ICE é composto por Conselho Supervisor (2); Core Team (3); Administrativo/financeiro (7); Supervisores (5); Gerentes de projeto (3), Consultores de gestão (11) e Consultores pedagógicos (12). É a partir de grupos como o ICE que é visível perceber as relações de hegemonia no país, a configuração de APHs na sociedade civil e sua relação com o movimento político-empresarial. Desse modo, Martins afirma

que, no curso da história brasileira recente, uma fração da classe empresarial atualizou as formas de intervenção na educação por meio de novos mecanismos político-ideológicos e pedagógicos, com o objetivo de sedimentar o seu projeto de formação humana como referência para toda a sociedade. (MARTINS, 2015, p. 292)

Contudo, o empresariado se apresenta como independente e busca afirmar isso por meio de várias estratégias. Shiroma (2015) aponta que se assumem como "sociedade civil” interessada em melhorar a qualidade da educação e conseguem não só penetrar num mercado protegido, mas conquistar a exclusividade para realizar as suas atividades. Desse modo, a parceria estabelecida entre o ICE e as SEE apresenta-se cada vez mais

\footnotetext{
7 Art. $2^{\circ} \mathrm{A}$ educação, dever da família e do Estado, inspirada nos princípios de liberdade e nos ideais de solidariedade humana, tem por finalidade o pleno desenvolvimento do educando, seu preparo para 0 exercício da cidadania e sua qualificação para o trabalho. (BRASIL, 1996).

${ }^{8}$ Art. $3^{\circ}$ Constituem objetivos fundamentais da República Federativa do Brasil: I - construir uma sociedade livre, justa e solidária; II - garantir o desenvolvimento nacional; III - erradicar a pobreza e a marginalização e reduzir as desigualdades sociais e regionais; IV - promover o bem de todos, sem preconceitos de origem, raça, sexo, cor, idade e quaisquer outras formas de discriminação. (BRASIL, 1988).

9 Declaração mundial sobre educação para todos. Plano de ação para satisfazer as necessidades básicas de aprendizagem. (UNESCO, 1990).
} 
fortalecida. Por isso, é importante representar o passo a passo que se firma entre os parceiros (Esquema 1). Essa situação “da parceria à passagem de bastão” revela o mecanismo que o ICE utiliza com objetivo de obter a licença para atuar em nome do Governo, sem que com isso seja rotulado como o próprio Governo. Essa estratégia evita que a imagem do Governo seja associada à sua logomarca.

Esquema 1 - O passo a passo "da parceria à passagem de bastão": ciclo de três anos (2019)

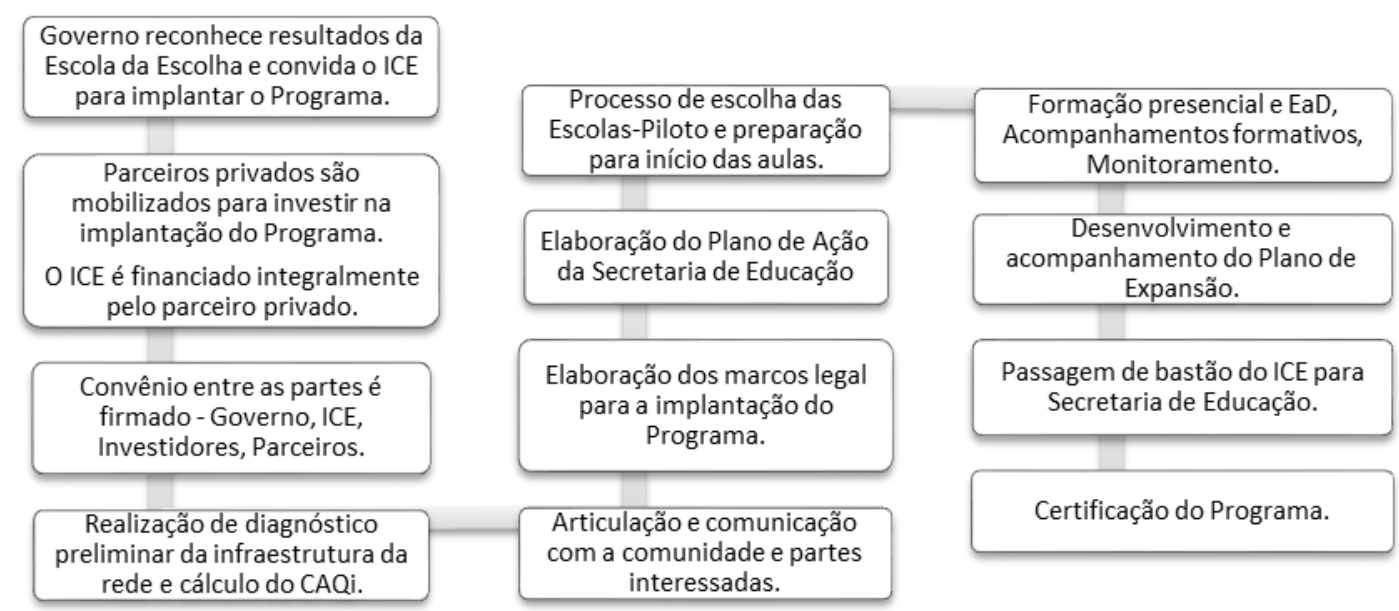

Fonte: ICE (2019), com adaptações do autor.

Essas empresas têm uma participação ativa, pois não é um mero fornecimento de serviço em educação, ela vai além - envolve o pensar, planejar e definir as formas de trabalho. Não é uma atividade estritamente técnica, mas uma oportunidade do empresariado definir uma política educacional pública e atuar como co-planejador de políticas, partícipes da governança da educação pública. Dessa forma, Shiroma (2015, p. 72) infere que “outra consequência deste tipo de terceirização na educação, além da mercantilização de serviços é a redução de poder público na definição de políticas públicas." Mas, para que esse percurso aconteça, o ICE busca estabelecer uma relação entre diferentes sujeitos, a qual designa de "corresponsabilidade". Tal palavra compõe seu próprio nome e é expressa a seguir (Esquema 2): 
Esquema 2 - A ideia de corresponsabilidade do ICE (2019)

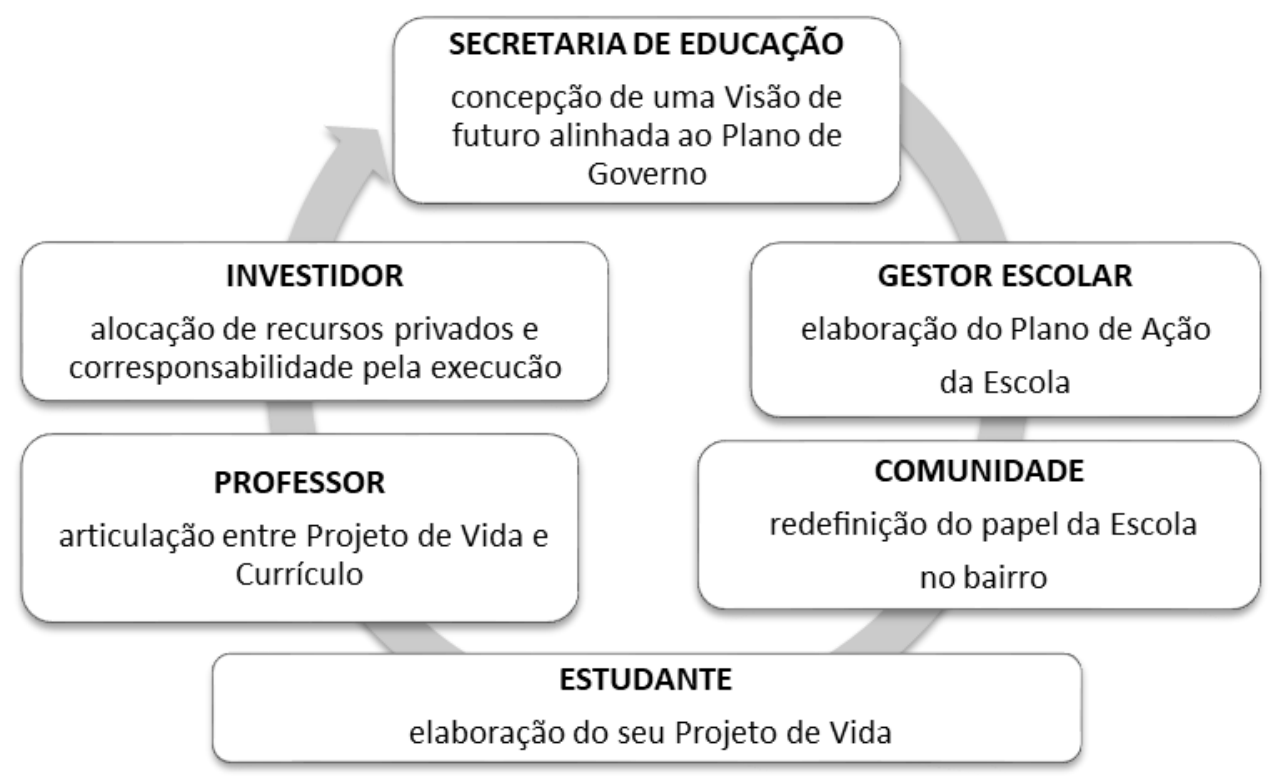

Fonte: ICE (2019), com adaptações do autor.

A ideia de corresponsabilidade corresponde à construção teórica da Terceira Via, a qual conforme Giddens (2000, p. 42-43) "sugere que a governabilidade deve ser pensada como algo capaz de sintonizar as ações do ‘novo Estado democrático' com os organismos da sociedade civil." Tal governabilidade se trata de uma articulação entre as esferas estatal-privada de onde também decorre a noção de "público não-estatal”. A palavra corresponsabilidade sugere a participação ${ }^{10}$ da comunidade, mas na verdade, a proposta é responsabilizá-la e fazer crer que faz parte da solução dos problemas da educação e da escola.

As parcerias do ICE com outras empresas são classificadas em "Parceiros estratégicos" e "Parceiros técnicos", conforme destacadas no site e configuradas no quadro 1:

\footnotetext{
${ }^{10} \mathrm{O}$ conceito de participação é central na nova pedagogia da hegemonia direcionada à sustentação das políticas do neoliberalismo de Terceira Via. A nova pedagogia da hegemonia é composta por tentativas das classes dominantes em delimitar a participação popular à pequena política e deixar em segundo plano as reflexões e ações que buscam compreender e transformar a realidade social mais geral (NEVES, 2005, p. 34).
} 


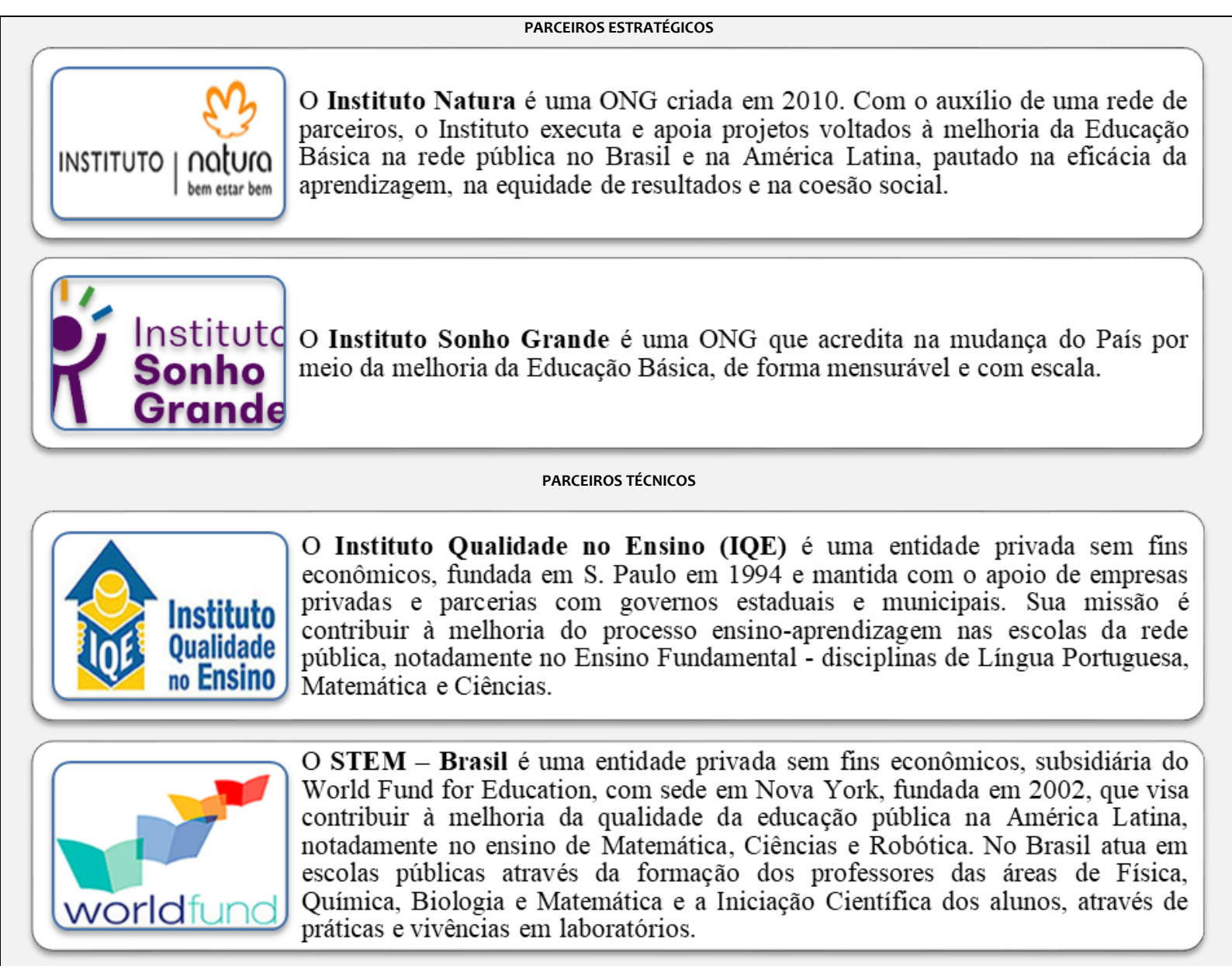

Fonte: ICE (2019), com adaptações do autor.

As parcerias estabelecidas entre estes grupos, independentemente de seus níveis, constituem a rede dos Aparelhos privados de Hegemonia ${ }^{11}$ que atuam sempre em benefício dos seus mercados. Além das parcerias, o ICE conta com vários investidores de diversos ramos empresariais, conforme demonstra o esquema 3 exposto a seguir. É evidente a relação do ICE com bancos, instituições financeiras, e outras consultorias, indicando que eles têm muitas situações de encontro e troca de informações, discussão, decisões e parcerias em diversos projetos.

\footnotetext{
${ }^{11}$ Conforme assevera Coutinho (2010, p. 70), "uma relação de hegemonia é estabelecida quando um conjunto de crenças e valores se enraíza no senso comum, naquela concepção de mundo [...] 'bizarra e heteróclita", frequentemente contraditória, que orienta "o pensamento e a ação de grandes massas de homens e mulheres". É exatamente nesse senso comum que se manifestam determinados valores e formas de pensar que "asseguram a reprodução do capitalismo" contemporâneo e se expressam na realidade atual, através de práticas concretas levadas a efeito por governos, organismos internacionais e outras instituições mediante as políticas neoliberais.
} 
Esquema 3 - Investidores do ICE (2021)

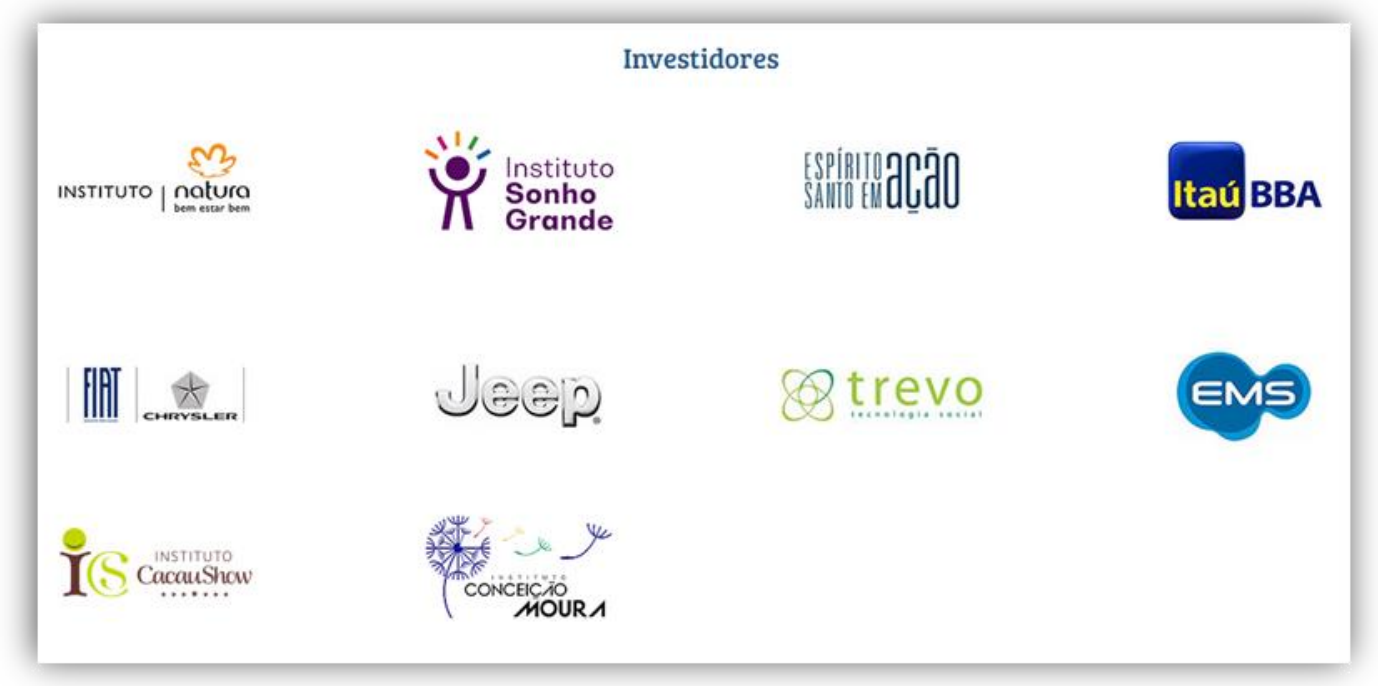

Fonte: ICE (2021).

Nesse caso, identifica-se que o ICE é um braço social das oito instituições empresariais demonstradas no esquema e tem, para eles, a função estratégica de valorizar a marca/produto do grupo, atuando na esfera da "responsabilidade empresarial”. Adrião analisa a situação apontando que:

estudos anteriores, a respeito da privatização da gestão da educação no Brasil, identifica três principais segmentos privados atuando junto às redes e sistemas públicos: os filantropos de risco ou venture philanthropy, as corporações propriamente ditas e os braços sociais dessas corporações, organizados em fundações e institutos. Com menor presença localizam-se organizações da sociedade civil articuladas a movimentos sociais. (ADRIÃO, 2018, p. 18)

Essa é uma estratégia mundial, inclusive seu objetivo-chave é citado por Adrião, de acordo com documento da OCDE (2014 apud ADRIÃO, 2018, p. 19, tradução da autora): “otimizar e acelerar o impacto da filantropia para o desenvolvimento através da partilha de experiências e lições, influência política e o desenvolvimento de parcerias inovadoras". Logo, o engajamento do empresariado com políticas sociais em prol da educação não é uma disposição espontânea, mas universalmente arquitetada por lideranças econômicas na busca de constituir alianças e redes que são primordiais na formulação de uma agenda global. Por esse motivo, Draxler afirma que: 
Em 2003, o Fórum Econômico Mundial (FEM) criou um programa intitulado Partnerships for Education para estimular o engajamento do setor privado, instituições acadêmicas e organizações nãogovernamentais (ONG) na gestão de 'recursos e habilidades'. Parcerias dessa natureza consubstanciaram a ideia de educação como um serviço público que pode ser fornecido por organizações sociais privadas. $\mathrm{Na}$ reunião do FEM de 2007, em Davos, foi estabelecida uma parceria entre o Fórum e a Unesco para alcançar as metas do Educação para Todos, enfatizando as contribuições do setor privado na educação pública. (DRAXLER, 2008 apud Shiroma, 2015, p. 59)

Esse mecanismo oportuniza a definição de prioridades, estratégias e metas para as políticas governamentais, partindo dos interesses empresariais por meio do compartilhamento de ideias, dados e projetos. Shiroma (2015, p. 73) também assevera que "essas empresas, com apoio das agências multilaterais, estão se engajando na produção da regulamentação, na redefinição de políticas públicas e do modo de fazer política." Logo, essas ações potencializam o contato em redes e criam a agenda global.

\section{Discursos privatistas na gestão da política de EMTI amapaense}

De acordo com Shiroma (2019, p. 90) quando se trata de compreender os objetivos de uma política educacional, "nota-se que determinações econômicas ficam ocultas aos educadores, gestores e grande público." Contudo, ao se analisar os discursos, percebe-se que o modo como o ICE tem atuado denota a feição privatista no processo de implementação, pois neste contexto é preciso também ter claro que os setores privados:

[...] não se limitam aos ganhos econômicos de curto prazo obtidos com os contratos de gestão, mas relacionam-se à restauração da hegemonia do capital no âmbito do Estado integral no sentido gramsciano do termo. Empresários do setor privado defendem e fazem coro pela ampliação de recursos destinados às áreas sociais, que se abrem como mercados promissores para as empresas privadas. [...] encontram espaço para operar na esfera pública, patrocinadas pela mão visível do Estado. (SHIROMA, 2015, p. 77)

Logo, o que interessa aos grupos empresariais ao prestarem seus serviços, além de lucros, é também a possibilidade de ter espaço reservado nas comissões que determinam os sentidos das políticas públicas, de fortalecer a imagem da empresa, de ter 
facilidades de acesso ao planejamento e aos fundos do setor público. No caso da pesquisa em tela, pode-se inferir que o ICE tem acesso aos dados de todas as escolas, em especial aos planos de governo, possibilitando-lhe mediar informações e apontar problemas para os quais poderão criar as soluções ou indicar seus parceiros para o Governo. O que está em jogo, a princípio, é o valor que essas informações produzem no mercado - elas asseguram a essas empresas vantagens competitivas - é o mesmo que possuir um "selo de qualidade e eficiência," pois prestam serviços ao Governo. O poder de tais organizações se multiplica em função de:

não serem meras fornecedoras de serviços, mas, como inspetoras, têm possibilidade de sugerir o que deve ser reformado no sistema educacional. Ou seja, além de prestarem serviços, por identificarem os problemas, podem ser as primeiras a oferecem soluções ao governo. (SHIROMA, 2015, p. 68)

Dito de modo diverso, os interesses do setor privado sobre a área educacional superam abundantemente a cobrança de mensalidades. Shiroma (2019, p. 102) salienta que "este é um canal de acesso a informações privilegiadas sobre as áreas de interesse prioritário, onde o Governo vai investir, os produtos e serviços que serão demandados, e a oportunidade de desfrutar das vantagens de ter o Estado como cliente." Nessa dinâmica, o mercado se torna potencial para o capital, por meio da disposição de produtos e serviços para o setor público. Essa estratégia se expressa no relato do Consultor ICE 2:

Quando houve a expansão do ICE, até por conta das portarias que foram publicadas - Portaria MEC 1 e 2 - eles me convidaram para trabalhar como consultora pedagógica. (Consultor ICE 2, 2018. Informação verbal)

Isso representa que a expansão do ICE nesse serviço se deu com as portarias relacionadas ao EMTI, evidenciando assim a ideia de sustentabilidade mencionada por Martin e Thompson, a qual está relacionada à característica: 
'habilidade da empresa identificar áreas em desenvolvimento e geração de receitas em longo prazo'. Empresas visam arrebanhar contratos com o governo que tenham potencial para desencadear uma longa cadeia de serviços públicos que possam ser providos pelo setor privado. (MARTIN; THOMPSON, 2010 apud SHIROMA, 2015, p. 67-68)

Assim sendo, pode-se inferir que o ICE possui um acesso privilegiado de informações junto ao Governo e busca tal sustentabilidade, pois ao mesmo tempo em que demanda a necessidade da política, neste caso de EMTI, ele também oferta seus serviços para o Estado. Afirma-se ainda que, por diferentes ambições, empresas privadas buscam atuar no campo da política educacional, principalmente pelo acesso das informações privilegiadas e ao fundo público que lhes possibilitam produzir o lucro. Desse modo, Shiroma (2019) indica que o empresariado obtém nas políticas públicas para educação um espaço próspero para ganhos econômicos e políticos: vende seus produtos e assegura a difusão dos valores, informações e metodologias para fomentar a sociabilidade requerida pelo capital no século XXI, tanto é que o ICE fornece consultoria para governos de várias cidades, oferecendo suporte e gerenciando seus programas de reformas nacionais. Conforme elucida o Consultor ICE 1:

[...] A gente não se convida. A gente só vai onde é convidado. E eu acho que tem muita gente boa, interessada em poder colaborar com o poder público, com uma educação de qualidade. Eu não vejo como uma ameaça ao fim da educação pública e gratuita aqui no Brasil. Acho que é, muito dos institutos que eu conheço, quando você olha para os estatutos deles, eles são bem claros quanto à visão, missão, valores. E enfim, essa é a minha visão. E eu acho que no Brasil 'tá tendo uma mudança de visão em relação a isso. Porque assim, público e privado existe um muro gigantesco entre eles. Não, não é assim. Eu acho que principalmente o terceiro setor no Brasil, principalmente quando a gente compara com outros países - Estados Unidos, países europeus, eu acho que é bem estruturado. Uns com 15, 20 anos, com condições fortes de apoiar o governo. Daí eu cito o ICE, Vetor Brasil, Fundação Lemann, enfim. (Consultor ICE 1, 2018. Informação verbal)

Neste sentido, Ginsburg (2012 apud SHIROMA, 2015, 70-71) sustenta que "parcerias público-privadas servem como um cavalo de Tróia para privatizar responsabilidades do governo." Logo, dentre os tipos de operações em que o Terceiro Setor influencia diretamente na prestação dos serviços públicos à população, pode-se 
dizer que essa relação do ICE com o EMTI no Amapá é uma co-governança. Pois, para Callon, a co-governança:

refere-se aos arranjos em que as organizações filantrópicas ou lucrativas atuam com órgãos públicos participando não só da oferta de serviços, mas também de seu planejamento e tomada de decisões, ou seja, tornam-se partícipes da governança. Essa prática é viabilizada pela formação de redes tecnicoeconômicas definidas como um conjunto coordenado de atores heterogêneos (laboratórios públicos, centros de pesquisa tecnológica, empresas, organizações financeiras, usuários e governos) que participam coletivamente na concepção, desenvolvimento, produção e distribuição ou difusão de procedimentos para produzir bens e serviços, alguns dos quais levam a transações mercantis. (CALLON, 2001 apud SHIROMA, 2015, p. 70)

Observa-se que toda a ideia denota a delegação pela esfera pública, dos meios inerentes às tomadas de decisão sobre os rumos da educação e os mecanismos necessários ao seu atendimento. E essa visão vai se "naturalizando" nos discursos:

[...] Não sei se você conhece um pouco da história do ICE, mas a ideia é pegar boas práticas de gestão de outras escolas, de governos, de empresas, adaptar a esse mundo chamado escola e tentar replicar Brasil afora essas boas práticas. (Consultor ICE 1, 2018. Informação verbal)

Em síntese, pode-se dizer que a solução para a "crise de qualidade" na educação, segundo os neoliberais, é a articulação da centralização do controle pedagógico (em nível curricular, de avaliação do sistema e de formação de docentes) e descentralização dos procedimentos de financiamento e gestão do sistema. Calcado nessa racionalidade, o Estado estimula e garante o privilégio da esfera privada e, assim, transforma as instituições sociais na área da Educação em empresas, neste caso a Escola, o que representa a redefinição do papel do Estado.

$\mathrm{Na}$ educação, os neoliberais introduziram o consenso de que os problemas educacionais decorrem da "ineficácia" da gestão. Afirmam que não faltam recursos para a área, e sim gestão, pois são mal geridos; alegam a necessidade de profissionais eficazes com competências para gerenciá-los. Baseados nesse discurso, "esse movimento colocou os diretores de escola no centro das agendas, responsabilizando-os pelo desenvolvimento de escolas eficazes." (SHIROMA, 2018, p. 92). Isso provocou a 
temporada de profissionalização de gestores e professores nos anos de 1990. Esses ideais estão presentes na atualidade. Tal observação está assentada no relatado dos entrevistados:

A minha função de consultor em gestão educacional [...] é, enfim, dar formações sobre o modelo de gestão pra essas pessoas, pra esses profissionais e além disso, participar dos Ciclos de Acompanhamento Formativo, onde eu, junto com uma consultora pedagógica do ICE, mais a equipe de implantação que, no caso, é a ETI, a gente visita as 8 escolas pertencentes ao programa de ensino integral e passamos um dia; tem um roteiro, existe uma pauta, existe um objetivo, existe um foco, onde o meu principal objetivo é tirar dúvidas, alinhar, dar pontos de atenção. Saber como a gestão da escola pode avançar em relação a pleno entendimento da aplicação do modelo de gestão do ICE para a educação em tempo integral. (Consultor ICE 1, 2018. Informação verbal)

Shiroma (2018) salienta que tais ideais são identificados, sobretudo nas recomendações de OM, que indicam o uso de tecnologias de informação e comunicação, bases curriculares e avaliações externas como elementos fundamentais para produzir escolas eficazes. Eficiência, informatização e qualidade tornaram-se o princípio do discurso da modernização educacional e aos poucos, os diretores são conhecidos como gerentes.

Os discursos sobre gestão escolar correspondem ao "bem-estar social"12 e ao "novo gerencialismo,"13 conforme discutem Gewirtz e Ball (2011), com base nos estudos de Clarke e Newman (1992): “[...] a reestruturação do Estado de Bem-Estar Social pela

\footnotetext{
${ }_{12}$ Bem-Estar Social (welfarism) é um termo guarda-chuva que abarca diversos conjuntos de conceitos frequentemente contraditórios. Abrange vasta gama de valores, práticas e opiniões divergentes sobre o que constitui o interesse público e sobre quais estratégias são mais adequadas para atendê-lo. [...] Dentre os discursos mais populares relacionados à educação no Bem-Estar Social, desde fins dos anos 1960, estão aqueles que giram em torno de compromissos ideológicos com igualdade de oportunidades, valorização de todas as crianças por igual, relações de igualdade e apoio, acolhimento, concepção centrada na criança, escola não seletiva, assimilacionismo, multiculturalismo, antirracismo, respeito à diversidade sexual, práticas não sexistas, desenvolvimento de cidadãos críticos, participação democrática e transformação social. Além disso, "gestão colegiada, atendimento, profissionalismo e não exploração são valorizados" (CLARKE; NEWMAN, 1992 apud GEWIRTZ; BALL, 2011, p. 198).

${ }^{13}$ [...] Vê o sistema de controle burocrático pesado, contraproducente e repressivo do "espírito empreendedor" de todos os empregados. Sua noção de caminho para o sucesso competitivo está em flexibilizar os sistemas formais de controle [...] e enfatizar o valor de motivar as pessoas para produzir "qualidade" e esforçarem-se para conseguir "excelência". Os administradores se tornam líderes em vez de controladores, fornecendo as visões e inspirações que geram um compromisso coletivo ou corporativo em "ser o melhor" (NEWMAN; CLARKE, 1995 apud GEWIRTZ; BALL, 2011, p. 199).
} 
nova direita representa um ataque ao 'profissionalismo' e uma tentativa de substituí-lo por um 'novo regime gerencial."' É o que se identifica no relato a seguir:

O processo de gestão, assim, é desenvolver a gestão, [...] a gente tem o material do modelo pra nos fundamentar, e aí a partir do momento que eu começo a fugir desse material, eu sou chamado, o ICE me chama, no caso os consultores vêm me chamar, vêm esclarecer que a gente tem um modelo a seguir, a gente precisa fazer esse modelo [...] mas o ICE vem justamente pra nos fundamentar, pra nos dar essa base, essa sustentação, e eles têm os consultores de gestão, os consultores pedagógicos. (G8, 2019. Informação verbal)

Para melhor compreender essa análise, recorre-se a Gewirtz e Ball (2011, p. 200). Os autores apresentam a diferença entre liderança no Bem-Estar Social e a liderança gerencialista, tal como indicada adiante (Quadro 8):

Quadro 8 - Principais características do Bem-Estar Social e do novo gerencialismo

\begin{tabular}{|c|c|}
\hline Bem-Estar Social & Novo gerencialismo \\
\hline $\begin{array}{l}\text { Sistema de valores voltado ao serviço } \\
\text { público }\end{array}$ & Sistema de valores orientado ao cliente \\
\hline $\begin{array}{l}\text { Decisões guiadas pelo comprometimento } \\
\text { com "padrões profissionais" e valores, tais } \\
\text { como: igualdade, assistência, justiça social }\end{array}$ & $\begin{array}{l}\text { Decisões instrumentalistas guiadas pela eficiência, } \\
\text { custo-eficácia, busca por competitividade }\end{array}$ \\
\hline $\begin{array}{l}\text { Ênfase nas relações coletivas com os } \\
\text { funcionários - por meio dos sindicatos }\end{array}$ & $\begin{array}{l}\text { Ênfase nas relações individuais mediante } \\
\text { marginalização dos sindicatos e de novas técnicas } \\
\text { gerenciais, tais como Gerência da Qualidade Total } \\
\text { (GQT) e Gerência de Recursos Humanos (GRH) }\end{array}$ \\
\hline Consultiva & Autoritária \\
\hline Racionalidade substantiva & Racionalidade técnica \\
\hline Cooperação & Competição \\
\hline $\begin{array}{l}\text { Gerentes socializados dentro da área e } \\
\text { valores específicos do setor de Bem-Estar } \\
\text { Social: educação, saúde, assistência social }\end{array}$ & $\begin{array}{l}\text { Gerentes socializados gerencialmente, dentro da área } \\
\text { dos valores da "gerência" }\end{array}$ \\
\hline
\end{tabular}

Fonte: Gewirtz e Ball (2011, p. 200). 
Diante desses apontamentos, nota-se que o processo de implementação do EMTI no Amapá tem se dado pela tendência gerencial. Uma vez que, de forma geral, os sujeitos entrevistados evidenciam uma narrativa com os ideais desse tipo de gestão, em que estão implantando uma cultura escolar gerencial predominantemente em acordo com o discurso hegemônico do mercado e de valores empresariais:

[...] Quando eu comecei a trabalhar com instrumentos de gestão do meu tempo, do meu trabalho, quando comecei a trabalhar com os planejamentos de uma forma mais sistematizada, que a gente não costuma ter em algumas escolas. Então, que eu não tinha quando eu trabalhava na escola parcial lá. [...] Então assim a TGE [Tecnologia da Gestão Educacional], que é o nosso instrumento de gestão, nos auxilia a fazer um planejamento, a ver o todo da escola. Então a gente precisa trabalhar com descentralização, com delegação planejada, eu preciso ter confiança com quem trabalha comigo, conhecer, eu não posso cobrar que quem trabalha comigo chega no horário, se eu não chego no horário, eu preciso trabalhar pensando no "ciclo de melhoria contínua", eu atingir a minha meta. (ETI/AP, 2018. Informação verbal)

Nos discursos estão presentes as noções do gerencialismo e, na prática, o monitoramento aparece disfarçado de "apoio às escolas". Além disso, identifica-se também uma linguagem que desqualifica a Escola, em especial a do tempo parcial e a ideia de metodologia empregada nesse processo acaba por dissimular a ideia de conteúdo e sentido especificamente técnico, que é a Tecnologia de Gestão Educacional (TGE). Assim, para Santos:

Aqui também, o produto esconde o processo. Como no reino das mercadorias o valor de uso se subsume ao valor de troca, a substância à forma. [...] A indústria da Educação Privada é a forma mais adequada para o fim esperado, se for a distância, ainda melhor. Aqui também a eficácia, entendida como atingir os fins propostos com o menor gasto possível, tão difundida pelas Organizações Multilaterais, se manifesta em sua plenitude ideológica, escondendo a substância destruída em nome da forma reluzente das metas atingidas. (SANTOS, 2012, p. 08)

Em síntese, vive-se um esgotamento do conteúdo substantivo das práticas educativas como campo de pesquisa, formação profissional, criação de conhecimento e desenvolvimento humano. Para evidenciar esse modelo de gestão nas Escolas do Novo Saber, destacou-se o relato do G4 que detalha a prática: 
[...] Existe um material que é o Kit, são os livros do ICE, como eu te falei eles trazem um programa pronto, esse programa pronto ele te mostra como que você vai trabalhar, vai desenvolver cada uma das propostas: estudo orientado, eu tenho o guia, o livro que te ensina ou que te orienta como é que você vai fazer o estudo orientado; a TGE-Tecnologia de Gestão Educacional eu tenho um livro aonde ele te orienta como é que tem que ser a dinâmica da gestão escolar dentro da proposta do ensino de TI, eletiva, todas as situações que estão inseridas dentro desse contexto elas estão especificadas dentro dessa proposta que é o caderno do ICE, de onde vêm todos esses esclarecimentos. (G4, 2019. Informação verbal)

Esse relato, referente ao modelo TGE, apresenta termos específicos do consenso e da linguagem empresarial - tecnologia, qualidade, monitoramento, alinhamento e fluxo. Para o neoliberalismo, a fronteira de eficiência do sistema educacional seria possível quando a atividade educacional estivesse sob controle empresarial concorrendo em um livre mercado, sem intervenção do Estado. (FREITAS, 2018). Para Heloani (2018, p. 187), trata-se de "privatizar parcela significativa das organizações públicas e modificar o modelo da administração pública, ou melhor, introduzir princípios e pressupostos do setor privado para a esfera estatal. Fica evidente que na implementação do EMTI existe um modelo de gestão específico a ser seguido e que é baseado na cultura de metas, planilha de indicadores e avaliação, bem como são executadas práticas de monitoramento.

Nessa lógica, empresas de consultorias multiplicam-se negociando modelos, receitas e expertise, embasadas no discurso de que assim como salvaram empresas da crise, poderão também "salvar" as escolas. Para Shiroma (2018, p. 96), “evidencia-se o caráter instrumental da educação proposta pelo capital, por meio dos OM e a natureza interesseira do "direito à aprendizagem". Fica nítida a contradição desse modelo aparentemente direcionado ao estímulo do conhecimento, da inovação e da qualidade ao lado de medidas impulsionadoras da precarização e da desintelectualização dos profissionais de educação, neste caso, dos gestores e professores. Evangelista (2008) expõe que os reformadores internacionais buscam reconverter os professores definindo o que devem saber e podem fazer e, assim, pretendem reconfigurar a escola pública e enfraquecer os sindicatos e desorganizar as lutas coletivas. 
Tais práticas gerenciais são caracterizadas nos relatos dos entrevistados. Os sujeitos falam sobre os mecanismos de atuação do ICE no processo de implementação do EMTI, sobretudo das estratégias de trabalho desenvolvidas no interior das escolas:

\begin{abstract}
Bem, nós passamos pela formação continuada e recebemos uma orientação do ICE e posteriormente nós temos uma Equipe de Implantação dentro da SEED/AP [...] Também eles fazem um ciclo de acompanhamento que é o CAF (Ciclo de Acompanhamento de Formação), é realizado quatro CAF durante o ano [...] Aí nesse ciclo eles verificam como está o desenvolvimento da escola, é como se eles viessem medir o termômetro aqui, tá bem, tá mal, onde é que tá faltando e aí no ciclo eles vão ouvir, então normalmente vinham duas pessoas do ICE e mais três ou quatro técnicos da Equipe de Implantação, ele vêm, chegam às sete e trinta na escola, desde aquele momento que eles chegam já estão avaliando a escola [...] eles pegam todas as impressões da escola, [...], e eles fazem várias perguntas, aí a gente vai falando e depois eles chamam os estudantes, são líderes de turma e presidentes de clube, aí eles vêm $e$ deixam os meninos a vontade e eles começam a fazer várias perguntas para os meninos (na nossa presença), 'e aí, o que é que tem de bom na escola, o que é que tem de ruim? E aí, como é que estão as eletivas? Como é que está o estudo orientado? [...] $\left(\mathrm{G}_{3}, 2019\right.$. Informação verbal)
\end{abstract}

Esse relato, na essência, revela os mecanismos de controle que na lógica neoliberal são usados como estímulo à qualidade do ensino, mas ocultam as proposições do capital que neles estão implícitos. Por exemplo, as práticas de inspeção (monitoramento), sejam elas positivas ou negativas, que na linguagem do ICE são chamadas "metodologias de êxito ou pontos de atenção", acabam gerando sempre mais necessidades para as escolas e todos os seus agentes e, na sequência, para o Estado. Essas necessidades estão relacionadas à cultura gerencial: elevar os indicadores, melhorar os serviços e dar respostas à sociedade sobre as ações realizadas junto ao produto final alunos como mão de obra para o mercado.

Diante do exposto, pode-se afirmar que a gestão nas Escolas do Novo Saber tem um caráter antidemocrático e embasada na chamada nova gestão pública que inspira as reformas de Estado desde os anos 1990. A atuação do ICE, suas diretrizes e TGE definem o que as escolas, professores, estudantes e até as Secretarias de Educação devem fazer, demonstrando, assim, o poder do capital no campo das políticas educacionais e fazendo 
dos governos seus clientes em potencial. Portanto, está em vigor a reconfiguração do papel do Estado.

\section{Considerações finais}

A trajetória da implementação do EMTI amapaense é uma das manifestações da condição humana decorrentes do contexto capitalista; assim estabelece bases materiais de práxis alienada ao capital e à condição de mercadoria. O texto buscou destacar a dinâmica da produção das condições materiais pelas quais a referida política vem se estabelecendo nas Escolas do Novo Saber. Na essência, trata-se de um processo de reconfiguração do espaço público, por meio do qual os grupos empresariais, alegando o princípio do direito à educação de qualidade, ampliam sua atuação nas mudanças de políticas sociais e mantêm o aparente discurso de responsabilidade social empresarial, voluntariado e estímulo à responsabilidade social.

Nesse sentido, Mészáros (2005) afirma que o processo de privatização da educação pública tem avançado de diferentes formas, sendo parte das estratégias do capital para a superação de sua crise estrutural. Como consequência, nota-se a significativa reestruturação das relações de classe, que surgiu como resultado desses processos, especialmente em benefício das classes empresariais e em detrimento dos trabalhadores e das classes médias. É importante destacar que, neste contexto, as PPPE promovem o rápido avanço do liberalismo econômico, tanto que o setor privado está intrinsecamente presente nos serviços públicos e em especial na Educação, caso da nova configuração educacional no Amapá arquitetada pela consultoria do ICE nas Escolas do Novo Saber.

Discute-se esse fenômeno em que o setor público vem sendo "repensado" como oportunidade lucrativa para o capital, ficando assim clara a necessidade de se defender a gestão pública da educação pública e criticar as parcerias entre as esferas privada e pública como alternativa de política educacional. Tal postura deriva da noção de que o avanço da perspectiva neoliberal restringe direitos, desmonta o aparelho administrativo do Estado, desconsidera o pacto social estabelecido na Constituição de 1988 e, por fim, 
ameaça o símbolo civilizatório dos direitos humanos como fonte da sociabilidade, ainda que não percamos de vista seus limites.

O EMTI é uma política verticalizada em todos os seus níveis, desde a concepção, a elaboração dos documentos legais até sua implementação, perpassando a Secretaria de Educação e chegando até a Escola. Há na rede estadual 394 escolas, das quais foram selecionadas para implantação do EMTI, inicialmente, apenas oito escolas e em seguida mais 15, totalizando 23 Escolas do Novo Saber até o ano de 2020. Nesse sentido, seria o EMTI tratado como excelência na precariedade geral? Isso revela um dos aspectos negativos dessa proposição, na medida em que contribui para aprofundar a desigualdade que marca historicamente a Educação Básica no País.

Dessa forma, as políticas sociais como ações estatais são fundamentais para reparar os problemas - não todos, certamente, tendo em vista o acelerado processo de retirada de direitos que se enfrenta no momento - causados pelo modo de produção capitalista neoliberal. Tal é o caso da política de EMTI, em que se propõe ampliação do tempo na escola no Brasil como combate à fome e à pobreza - concepção de educação difundida pelo Banco Mundial e apropriada localmente com as alterações necessárias aos interesses burgueses internos. Busca-se implantar Escolas de tempo integral como política corretiva para dissimular as contradições do sistema capitalista, numa prática de financiamento a conta-gotas. Trata-se da apropriação da Educação como mercadoria pelo neoliberalismo, por meio de parcerias com organizações burguesas da sociedade civil terrenos de conflitos de classe - para garantir mão de obra para o mercado de trabalho. A política de Educação em Tempo Integral reafirma e reproduz os princípios básicos do neoliberalismo, pois observa-se que esse tipo de educação tem sido pensado pela burguesia para a classe operária com o objetivo de manter a desigualdade de classes desde os finais dos anos de 1980.

Observou-se por meio das entrevistas que a feição privatista se expressa ideologicamente na implementação do EMTI amapaense. Ressalta-se que os entrevistados não criam a política em nível federal e estadual diretamente, mas estão a seu serviço e seus discursos estão impregnados de perspectivas privatistas, o que os leva a recriarem essa política no momento de sua execução local. Foi possível, ainda compreender, com base na realidade amapaense, a transformação das redes públicas de 
ensino em mercadorias educacionais, a qual tem se dado pela relação que instituições privadas estabelecem com os gestores públicos. Em outras palavras, a busca do capital para que os sujeitos absorvam como suas as metas de reprodução do sistema, para que assim se conforme a escola ao interesse do capital. É preciso compreender as determinações da crise do capital e identificar que a questão de discussão não é "menos Estado ou mais Mercado" e sim da "articulação orgânica entre capital e Estado", que cria a ilusão reformista e oculta o sociometabolismo do capital.

Nota-se que o processo de implementação do EMTI no Amapá tem se configurado pela tendência gerencial. De forma geral, os sujeitos entrevistados evidenciam uma narrativa com os ideais desse tipo de gestão, implantando uma cultura escolar gerencial predominantemente em acordo com o discurso hegemônico do mercado e com valores capitalistas.

A situação se intensifica em 2020, com o contexto de pandemia do Covid-19, pois a crise capitalista que já é anterior à pandemia, se agravou e indica formas mais degradantes. Há a ameaça da educação pública, gratuita, laica e socialmente referenciada, pois a liberação de aulas a distância/remotas configura uma educação domesticadora, tecnicista e anti-intelectual. Anteriormente à pandemia, já havia as proposições de substituição gradual do modelo de educação presencial para o Ensino a distância. Agora essas propostas ganham ainda mais força, uma vez que atendem as demandas de vários grupos empresariais que em seu nicho de produtos têm as plataformas digitais para vender, além de outras estratégias apropriadas para o cenário. A discussão de fundo é sobre a permanência estudantil, a destruição da formação humana, a redução das possibilidades de escolha para jovens da classe trabalhadora. Nota-se que projeto educacional brasileiro proposto pela extrema direita é de uma educação alienante e restrita e, que impede a compreensão da realidade social. É um tipo de precarização do trabalho e do ensino.

A pesquisa possibilitou a produção de conhecimento sobre a política de EMTI que resulta em um contra discurso e um subsídio para a luta contra-Hegemônica na Educação. Por meio do estudo desenvolvido foi possível perceber as relações estabelecidas entre trabalho e capital, bem como o papel que nelas ocupam o Estado e a Educação. Dito de outro modo, a atuação governamental para implementação da ETI no estado Amapá tem 
reforçado a mercantilização do processo escolar, garantindo a hegemonia das políticas neoliberais no âmbito da educação.

\section{Referências}

ADRIÃO, Theresa M. F. A privatização dos processos pedagógicos: grupos editoriais e os negócios na educação básica. In: MARINGONI, Gilberto et al. (org.). O negócio da educação: aventuras na terra do capitalismo sem risco. São Paulo: Olho d' Água: Federação dos Professores do Estado de São Paulo (FEPESP), 2017.

ADRIÃO, Theresa M. F. Dimensões e formas da privatização da educação no Brasil: caracterização a partir de mapeamento de produções nacionais e internacionais. Currículo sem Fronteiras, UNICAMP, v. 18, n. 1, p. 8-28, jan./abr. 2018.

AMAPÁ. Decreto 4.446, de 19 dez. 2016. Cria o programa de Educação em Tempo Integral na rede estadual de ensino. Diário Oficial do Estado do Amapá. Macapá, p. 5-7.19 dez. $2016 a$.

AMAPÁ. GEA. Secretaria de Estado da Educação (SEED). Educação. Macapá: SEED, 2016b. Disponível em: http://www.seed.ap.gov.br.

AMAPÁ. GEA. Secretaria de Estado da Educação (SEED). Educação. Macapá: SEED, 2017c. Disponível em: http://www.seed.ap.gov.br.

AMAPÁ. Lei 2.283, de 29 dez. 2017 - Institui o Programa de Escolas do Novo Saber. Diário Oficial do Estado do Amapá. Macapá, p. 1-8. 29 dez. $2017 a$.

AMAPÁ.SEED. Educação. Macapá: SEED. 2017b. Disponível em: http://www.seed.ap.gov.br.

\section{BANCO MUNDIAL. Grupo Banco Mundial apresenta sua estratégia de parceria para o}

Brasil. Washington, 2017. Disponível em: https://www.worldbank.org/pt/news/pressrelease/2017/07/13/brazil-world-bank-group-presents-country-partnership-strategy. Acesso em: 15 ago. 2020. 
BANCO MUNDIAL. Systems Approach for Better Education (SABER). Washington, 2018. Disponível em: http://saber.worldbank.org/index.cfm?indx=8\&pd=12\&sub=0. Acesso em: 15 ago. 2020.

BRASIL. Ministério da Educação. Portaria n. 1.145, de 10 out. 2016. Institui o Programa de Fomento à Implementação de Escolas em Tempo Integral, criada pela Medida Provisória 746, de 22 set. 2016. Diário Oficial da União: seção 1. Brasília, DF, p. 23-25, 11 out. 2016.

BRASIL. Portaria 1.023, de 4 out. 2018. Estabelece diretrizes, parâmetros e critérios do Programa de Fomento às Escolas de Ensino Médio em Tempo Integral. Diário Oficial da União, Brasília, DF, p. 1-11. 4 out. 2018.

BRASIL. Lei 9.394, de $20 \mathrm{dez}$. 1996. Estabelece as diretrizes e bases da educação nacional. Diário Oficial da União, Brasília, DF, 23 dez. 1996.

BRASIL. Constituição (1988). Constituição da República Federativa do Brasil: promulgada em 5 de outubro de 1988. 4. ed. São Paulo: Saraiva, 1990.

Consultor ICE 1. [Entrevista cedida a] José Almir Viana Nunes, Macapá (AP), 1 jun. 2018.

Consultor ICE 2. [Entrevista cedida a] José Almir Viana Nunes, Macapá (AP), 1 jun. 2018.

COUTINHO, Carlos Nelson. A hegemonia da pequena política. In: OLIVEIRA, Francisco.; BRAGA, Ruy.; RIZEK, Cibele. (org.). Hegemonia às avessas. São Paulo: Boitempo, 2010.

ETI/AP. [Entrevista cedida a] José Almir Viana Nunes, Macapá (AP), 5 jun. 2018.

EVANGELISTA, Olinda. Rede Kipus e reconversão docente. In: ENCONTRO NACIONAL DE DIDÁTICA E PRÁTICA DE ENSINO/ENDIPE: Trajetória e processos de Ensinar e Aprender; lugares, memórias e culturas, 14., 2008. Porto Alegre. Anais [...] Porto Alegre: EdiPUCRS, 2008.

EVANGELISTA, Olinda; TRICHES, Jocemara. Professor(a): a profissão que pode mudar um país? In: EVANGELISTA, Olinda (org.). 0 que revelam os slogans na política educacional. 1. ed. Araraquara: Junqueira \& Marin, 2014.

EVANGELISTA, Olinda. De protagonistas a obstáculos: Aparelhos Privados de Hegemonia e conformação docente no Brasil. Florianópolis: UFSC, 2021. Mimeografado.

FREITAS, Luiz C. de. A reforma empresarial da educação: nova direita, velhas ideias. São Paulo: Expressão Popular, 2018.

GAMBOA, Silvio Sánchez. Pesquisa em educação: métodos e epistemologias. Chapecó: Argos, 2007.

GEWIRTZ, Sharon; BALL, Stephen J. Do modelo de gestão do "Bem-Estar Social” ao "novo gerencialismo": mudanças discursivas sobre gestão escolar no mercado 
educacional. In: BALL, Stephen J.; MAINARDES, Jefferson (org.). Políticas educacionais: questões e dilemas. São Paulo: Cortez, 2011.

GIDDENS, Anthony. A terceira via: reflexões sobre o impasse político atual e o futuro da social-democracia. Rio de Janeiro: Record, 2000.

GRAMSCI, A. Concepção dialética da história. Rio de Janeiro: Civilização Brasileira, 1978.

GRAMSCI, Antônio. Concepção dialética da história. Rio de Janeiro: Civilização Brasileira, 1989.

GRAMSCI, Antonio. Cadernos do Cárcere. Rio de Janeiro: Civilização Brasileira, 2011. v.3. G3. [Entrevista cedida a] José Almir Viana Nunes, Macapá (AP), 16 dez. 2019.

G4. [Entrevista cedida a] José Almir Viana Nunes, Macapá (AP), 12 dez. 2019.

G8. [Entrevista cedida a] José Almir Viana Nunes, Macapá (AP), 17 dez. 2019.

HELOANI, Roberto. Modelos de gestão e educação: gerencialismo e subjetividade. São Paulo: Cortez, 2018.

INSTITUTO DE CORRESPONSABILIDADE PELA EDUCAÇÃO (ICE). Home ICE: sobre o ICE. Recife: ICE, 2019. Disponível em: http://icebrasil.org.br. Acesso em: 19 set. 2019

INSTITUTO DE CORRESPONSABILIDADE PELA EDUCAÇÃO (ICE). Home ICE: atuação. Recife: ICE, 2021. Disponível em: http://icebrasil.org.br. Acesso em: 25 jan. 2021.

INSTITUTO SONHO GRANDE (ISG). Home ISG: sobre o Instituto Sonho Grande. [S. I.]: ISG, 2019. Disponível em: http://www.institutosonhogrande.org. Acesso em: 20 out. 2019.

INSTITUTO NATURA. Home Instituto Natura: quem somos. [São Paulo]: Instituto Natura, 2019. Disponível em: https://www.institutonatura.org.br. Acesso em: 13 nov. 2019.

LAMOSA, R. A encruzilhada da Educação e a batalha das ideias. Esquerda online. Disponível em: https://esquerdaonline.com.br/2020/08/14/a-encruzilhada-da-educacao-e-a-batalhadas-ideias/. Acesso em: 21 ago. 2020.

MARTINS, André Silva. Formulações da classe empresarial para a formação humana: da educação política à educação escolar. Revista Contemporânea de Educação, [Rio de Janeiro], v. 10, n. 20, p. 291-313, jul/dez 2015.

MÉSZÁROS, István. A educação para além do capital. São Paulo: Boitempo, 2005.

NEVES, Lúcia Maria Wanderley. A nova pedagogia da hegemonia: estratégias do capital para educar o consenso. São Paulo: Xamã, 2005.

ORLANDI, Eni Puccinelle. Discurso fundador. Campinas: Pontes, 1993. 
SANTOS, Fabiano Antonio. O plano de desenvolvimento da escola e a produção do consentimento ativo. 2012. Tese (Doutorado em Educação). Universidade Federal de Santa Catarina, Florianópolis, 2012.

SHIROMA, Eneida; SANTOS, Fabiano Antonio dos. Slogans para a construção do consentimento ativo. In: EVANGELISTA, Olinda. $\mathbf{O}$ que revelam os slogans na política educacional. 1. ed. Araraquara: Junqueira \& Marin, 2014.

SHIROMA, Eneida Oto. O Estado como cliente: interesses empresariais na coprodução da inspeção escolar. Trabalho Necessário, Santa Catarina, 2015, 13, n. 22, p. 57-79, 2015. Disponível em: www.uff.br/trabalhonecessario. Acesso em: 13 jun. 2020.

SHIROMA, Eneida Oto. Gerencialismo e formação de professores nas agendas das Organizações Multilaterais. Momento: diálogos em educação, Santa Catarina, v. 27, n. 2, p. 88-106, maio/ago. 2018.

MELGAREJO, Mariano M.; SHIROMA, Eneida Oto. O projeto de educação do Banco Interamericano de Desenvolvimento. Roteiro, [S. I.], v. 44, n. 3, p. 1-24, 2019.

UNESCO. Declaração mundial sobre educação para todos. Plano de ação para satisfazer as necessidades básicas de aprendizagem. Tailândia: CEPAL/UNESCO, 1990. 